\title{
ЯЗЫКОЗНАНИЕ
}

UDC 811.11-112.+811.112.4

Tjeerd de Graaf

Frisian Academy and the European Research Centre

on Multilingualism and Language Learning, The Netherlands

\section{DUTCH, FRISIAN AND LOW GERMAN: THE STATE LANGUAGE OF THE NETHERLANDS AND ITS RELATIONSHIP WITH TWO GERMANIC MINORITY LANGUAGES. PART 1}

The primary involvement of the Fryske Akademy (Frisian Academy) lies in the domain of history, literature and culture related to the West Frisian language. The users of its nearest relatives, the East and North Frisian languages in Germany, are less numerous and these languages are included into the list of most endangered languages of Europe. This report describes the present day position of the Frisian language as one of the minority and regional languages of Europe and considers the relationship of Dutch with Frisian and the Low German dialects in the Netherlands (where it is called Low Saxon) and other parts of the world. Sections on the language characteristics, its speakers, language use, multilingualism, language policy, are followed by a survey of organizations which are involved in the documentation and safeguarding of Frisian and other regional and minority languages in Europe: the Fryske Akademy and the Mercator European Research Centre on Multilingualism and Language Learning. One of the subjects for study is the possible effect the new media have on the use of norms in the written language. This survey can be useful for the study and safeguarding of minority language situations elsewhere in the world.

Keywords: Frisian language, Low German, West-Germanic subgroup, minority languages, multilingualism, language policy, Frisian Academy.

Тьерд де Грааф

Фризская академия, Европейский исследовательский иентр многоязычия и обучения языкам, Нидерланды

НИДЕРЛАНДСКИЙ, ФРИЗСКИЙ И НИЖНЕНЕМЕЦКИЙ: ГОСУДАРСТВЕННЫЙ ЯЗЫК НИДЕРЛАНДОВ И ЕГО СООТНОШЕНИЕ С ДВУМЯ «МАЛЫМИ» ГЕРМАНСКИМИ ЯЗЫКАМИ. ЧАСТЬ 1

Главная задача, стоящая перед Фризской академией, заключается в изучении истории, литературы и культуры, связанных с западно-фризским языком. 
В Германии бытуют два близкородственных к западно-фризскому языка: восточно- и северно-фризский, однако носителей этих языков настолько мало, что эти языки занесены в список языков Европы, находящихся под угрозой исчезновения. В данной статье описано сегодняшнее положение фризского языка как одного из языков меньшинств и региональных языков Европы, а также рассмотрено родство фризского языка с нидерландским и с нижненемецкими диалектами в Нидерландах (где они называются «нижнесаксонским языком») и в других странах мира. После разделов, посвященных описанию самих языков, их носителей, сфер употребления, многоязычия и языковой политики, следует обзор организаций, призванных сохранять фризский и другие региональные языки Европы (Фризская академия и Меркаторовский центр по исследованию многоязычия и изучения языков в Европе). Один из аспектов исследования то влияние, которое новые средства информации могут оказать на нормы письменного языка. Данный обзор может быть полезен для изучения и сохранения языков меньшинств в любой точке мира.

Ключевые слова: фризский язык, нижненемецкий язык, западногерманские языки, малые языки, многоязычие, языковая политика, Фризская академия.

\section{GENERAL REMARKS ON FRISIAN AND LOW GERMAN}

Frisian (in the language itself called Frysk, in Dutch: Fries) is spoken in the north-western part of Europe and it has its most important branch in the province of Friesland in the Netherlands [Tiersma, 1985]. When the distinction with the smaller branches in Germany (North Frisian and East Frisian) has to be made it is also called West-Frisian (not to be confused with the geographic name West-Friesland for the Northern part of the province Noord-Holland). The three languages - West Frisian, East Frisian and North Frisian - are not mutually comprehensible. In the following we shall limit ourselves to the most important member of the language group, West Frisian in the Netherlands, which henceforth will be referred to as 'Frisian'.

The Frisian language belongs to the family of Germanic languages. In this family the coastal West Germanic subgroup is represented by English and Frisian, whereas the continental subgroup consists of (High and Low) German and Dutch. Historically (in the time before the AngloSaxons went to the British Isles) Old Frisian and Old English were very similar. As late as the $8^{\text {th }}$ century the Germanic languages Old Saxon, Old Franconian, Old Frisian, etc. were still close to each other. During the whole of the Middle Ages Friesland was monolingual and autonomous, under the leadership of frequently changing tribal chiefs. Old Frisian was not only the spoken language but also the official language of 
government and judicial power. Old Frisian laws and legal documents have survived from the $13^{\text {th }}$ century.

Modern Frisian still shares certain features with English, but the influence of Dutch and similarity with this language has become very strong. This is due to the fact that after the $16^{\text {th }}$ century, Dutch was used as the official language of the Netherlands in the halls of government, the judiciary, in schools and churches. Frisian virtually ceased being used in written form until a revival occurred at the end of the $19^{\text {th }}$ century. Since then Frisian has gradually regained access to more areas of life and developed into Modern Frisian. In recent decades it has acquired a modest place (alongside Dutch) in government, the judiciary and education.

Low German or Low Saxon (Plattdüütsch, Nedderdüütsch; Standard German: Plattdeutsch or Niederdeutsch; Dutch: Nedersaksisch) is a West Germanic language group spoken mainly in northern Germany and the eastern part of the Netherlands [Sanders, 1982]. It is descended from Old Saxon in its earliest form. The historical region where Low German was spoken also included contemporary northern Poland, the Kaliningrad Oblast of Russia, and a part of southern Lithuania. The former German communities in the Baltic states also spoke Low German. Moreover, in the Middle Ages Low German was the lingua franca of the Hanseatic League, and it had a significant influence on the Scandinavian languages.

Dialects of Low German are widely spoken in the north-eastern area of the Netherlands (Dutch Low Saxon) and are written there with an orthography based on Standard Dutch. Variants of Low German are still to a certain extent spoken in most parts of Northern Germany, for instance in the states of Lower Saxony, North Rhine-Westphalia, Hamburg, Bremen, Schleswig-Holstein, Mecklenburg-Vorpommern, Saxony-Anhalt and Brandenburg. The language was also formerly spoken in the outer areas of what is now the city-state of Berlin, but in the course of urbanization and national centralization in that city, the language has vanished. Under the name Low Saxon, there are speakers in the Dutch north-eastern provinces of Groningen, Drenthe, Stellingwerven (part of Friesland), Overijssel and Gelderland, in several dialect groups per province.

There are also immigrant communities where Low German is spoken in other parts of the world, including Russia, Canada, the United 
States, Mexico, Belize, Venezuela, Bolivia, Argentina, Brazil, Paraguay and Uruguay. In some of these countries, the language is part of the Mennonite religion and culture. There are Mennonite communities in Ontario, Saskatchewan, Alberta, British Columbia, Manitoba, and Minnesota which use Low German in their religious services and communities. These Mennonites are descended from primarily Dutch and Frisian settlers who had initially settled in the Vistula Delta region of Prussia in the $16^{\text {th }}$ and $17^{\text {th }}$ centuries before moving to newly acquired Russian territories in Ukraine in the late $18^{\text {th }}$ and early $19^{\text {th }}$ centuries and then to the Americas in the $19^{\text {th }}$ and early $20^{\text {th }}$ centuries. Mennonite colonies in Paraguay, Belize, and Chihuahua, Mexico have made Low German which they call Plautdietsch - a "co-official language" of the community [Epp, 1993; Nieuweboer, 1999].

\section{Language characteristics for Frisian}

The modern Frisian language has an official standard for the writing system. There has been a revision of the spelling in the second half of the $20^{\text {th }}$ century, but at the moment no changes are underway. The prescriptive norm for the Frisian language is described in Frisian Reference Grammar by Pieter Meijes Tiersma [Tiersma, 1985] and in the grammars written in Japanese by Kodama [Kodama, 1992] and Shimizu [Shimizu, 2006]. This norm of standard Frisian is officially promoted in schools and administration, but the overall dominance of the Dutch language makes the promotion difficult. For details about the grammar of modern Frisian we refer to Tiersma [Tiersma, 1985], which is the only grammar of Frisian currently available in English and which describes the correspondences and contrasts with English. Together with the Frisian-English dictionary, which the Fryske Akademy has published in 2000, the book provides a useful source of information for those interested in the Frisian language.

Although there are many contrasts with English, Frisian is genetically the closest related language to English. The tremendous influence of French on English and of Dutch on Frisian, along with natural changes over time, has obscured this, but even today certain features common to Frisian and English (as opposed to Dutch and German) document this relationship. One common development in English and Frisian is that $e g$ became an $e i$ or $a i$ sound in certain positions, as the following words attest: 


$\begin{array}{cccc}\text { Frisian } & \text { English } & \text { Dutch } & \text { German } \\ \text { dei } & \text { day } & \text { dag } & \text { Tag } \\ \text { rein } & \text { rain } & \text { regen } & \text { Regen } \\ \text { wei } & \text { way } & \text { weg } & \text { Weg } \\ \text { neil } & \text { nail } & \text { nagel } & \text { Nagel }\end{array}$

A related similarity is that $g$ was converted to $j$ (the sound of English $y$ ) in both languages under specific conditions:

$\begin{array}{clll}\text { Frisian } & \text { English } & \text { Dutch } & \text { German } \\ \text { jilde } & \text { yield } & \text { gelden } & \text { gelten } \\ \text { jern } & \text { yarn } & \text { garen } & \text { Garn } \\ \text { juster } & \text { yester(day) } & \text { gister } & \text { gestern }\end{array}$

In much the same way, $k$ became $c h$ in English and $t s j$ (which sometimes becomes $t s$ ) in Frisian:

$\begin{array}{llll}\text { Frisian } & \text { English } & \text { Dutch } & \text { German } \\ \text { tsjerke } & \text { church } & \text { kerk } & \text { Kirche } \\ \text { tsiis } & \text { cheese } & \text { kaas } & \text { Käse } \\ \text { tsjef } & \text { chaff } & \text { kaf } & \text { Kaff }\end{array}$

In a further development, the $n$ before a voiceless fricative $(f, t h$, or $s)$ was largely lost in Old English and Old Frisian:

$\begin{array}{llll}\text { Frisian } & \text { English } & \text { Dutch } & \text { German } \\ \text { ús } & \text { us } & \text { ons } & \text { uns } \\ \text { goes } & \text { goose } & \text { gans } & \text { Gans } \\ \text { oar } & \text { other } & \text { ander } & \text { ander }\end{array}$

The Frisian language has a rich vowel inventory, containing nine short and nine long vowels, along with a large variety of diphthongs. It should be taken into account that in particular the pronunciation of the vowels is subject to dialectal variation. The system of diphthongs contains many changing vowel sounds like /ai/ in the word <dei> ('day'). A specific phenomenon is called 'breaking', where falling diphthongs change into rising diphthongs, e.g. in the plural formation from $<$ doar $>$ [doər] ('door') ctree'). See for more details Tiersma [Tiersma, 1985] and De Graaf and Tiersma [De Graaf, Tiersma, 1980]. The consonant system of Frisian is for a great part similar to the English and Dutch one. In contrast to English, initial voiceless stops are pronounced without aspiration. 
The orthography of Frisian is based on the Roman alphabet and differs from the English and Dutch writing systems by the use of a few diacritics and double graphemes, introduced for the distinction of certain vowel sounds. For example: the graphemes $<\mathrm{ii}>(/ \mathrm{i}: /)$ and $<\hat{\mathrm{u}}>(/ \mathrm{u}: /)$ are only used in Frisian for the corresponding sounds, as is illustrated in the following words:

$\begin{array}{llllll}\text { Frisian } & \text { wiid } & \text { wyt } & \text { wiet } & \text { (ik) wit } & \text { hûs } \\ \text { Dutch } & \text { wijd } & \text { wit } & \text { nat } & \text { (ik) weet } & \text { huis } \\ \text { English } & \text { wide } & \text { white } & \text { wet } & \text { (I) know } & \text { house }\end{array}$

The Frisian writing system is more in correspondence with the pronunciation than is the case for Dutch and English. This is illustrated by the fact that the grapheme $<\mathrm{x}>$ is always replaced by $<\mathrm{ks}\rangle$ and initially the graphemes $\langle\mathrm{v}>$ and $<\mathrm{z}>$ do not occur in written texts. The graphemes $<\mathrm{x}>$ and $<\mathrm{q}>$ can only occur in names or obviously foreign words.

\section{Classification of Low German and related languages}

Low German is a part of the continental West Germanic dialect continuum. To the West, it blends into the Low Franconian languages and to the South it blends into the High German dialects of Central German that have been affected by the High German consonant shift. The division is usually drawn at the Benrath line that traces the maken machen isogloss. To the East, it meets the Polish language and to the North and North-West the Danish and the Frisian languages. Note that in Germany, Low German has replaced the Frisian languages in many regions. The Saterland Frisian is the only remnant of the East Frisian language and is surrounded by Low German, as are the few remaining North Frisian varieties. The Low German dialects of those regions have influences from Frisian substrates.

There is a distinction between the German and the Dutch Low Saxon/Low German situation. After mass education in Germany in the $19^{\text {th }}$ and $20^{\text {th }}$ centuries the slow decline which Low German was experiencing since the end of the Hanseatic League turned into a free fall. In the early $20^{\text {th }}$ century, scholars in the Netherlands argued that speaking dialects hindered language acquisition, and it was therefore strongly discouraged. Many parents, however, continued to speak Low Saxon with their children, since they could not speak anything else, nor did they need to; many of the Eastern Dutch towns and villages were largely selfreliant, and located far from the economic heart of the country. 
As education improved, and mass communication became more widespread, the Low Saxon dialects declined, but never disappeared. People in the Netherlands born up to the 1980s often have one of the Low Saxon dialects as their first language, although decline has been greater in urban centers of the Low Saxon regions. When in 1975 dialect folk and rock bands became successful with their overt disapproval of what they experienced as "misplaced Dutch snobbery" and the western Dutch contempt for (speakers of) Low Saxon dialects, they quickly gained an enormous following among the more rurally oriented inhabitants of the Netherlands, launching Low Saxon as a vibrant subculture, which has been very lively right up to the present day.

Today efforts are made in Germany and in the Netherlands to protect Low German as a regional language. Various Low German dialects are understood by 10 million people, and native to about 3 million people all around northern Germany. Most of these speakers are located in rural villages and are often elderly. In the Netherlands, Low Saxon is still spoken more widely than in Northern Germany. A 2005 study showed that in the Twente region of the Netherlands $62 \%$ of the inhabitants used Low Saxon daily as a spoken language, and up to $75 \%$ regularly.

\section{Sound changes related to Low German and orthography}

Low German is a West Germanic language of the lowlands and as such did not experience the High German consonant shift. The table below shows the relationship between the English and Low German consonants which were unaffected by this chain shift and gives examples in other modern Germanic languages, which were affected.

$\begin{array}{ccllllll}\begin{array}{c}\text { Proto- } \\ \text { Germanic }\end{array} & \begin{array}{c}\text { High } \\ \text { German }\end{array} & \begin{array}{c}\text { Low } \\ \text { German }\end{array} & \text { Dutch } & \text { English } & \text { German } & \text { Frisian } & \text { Swedish } \\ \mathrm{k} & \mathrm{ch} & \text { maken } & \text { maken } & \text { make } & \text { machen } & \text { meitsje } & \text { maka } \\ \mathrm{d} & \mathrm{t} & \text { Dag } & \text { dag } & \text { day } & \text { Tag } & \text { dei } & \text { dag } \\ \mathrm{t} & \mathrm{ss} & \text { eten } & \text { eten } & \text { eat } & \text { essen } & \text { ite } & \text { äta } \\ \mathrm{t} & \mathrm{z}(\widetilde{\mathrm{ts}} /) & \text { teihn } & \text { tien } & \text { ten } & \text { zehn } & \text { tsien } & \text { tio } \\ \mathrm{t} & \mathrm{tz}, \mathrm{z}(\widetilde{\mathrm{ts}} /) & \text { sitten } & \text { zitten } & \text { sit } & \text { sitzen } & \text { sitte } & \text { sitta } \\ \mathrm{p} & \mathrm{f}, \mathrm{ff} & \text { Schipp } & \text { schip } & \text { ship } & \text { Schiff } & \text { skip } & \text { skepp } \\ \mathrm{p} & \mathrm{pf} & \text { Peper } & \text { peper } & \text { pepper } & \text { Pfeffer } & \text { piper } & \text { peppar } \\ \beta & \mathrm{b} & \text { Wief, } & \text { wijf, } & \text { wife, } & \text { Weib, } & \text { wiif, } & \text { viv }\end{array}$


Generally speaking, the Low German grammar shows similarities with the grammars of Dutch, Frisian, English, and Scots, but the dialects of Northern Germany share some features (especially lexical and syntactic features) with German dialects.

The Low German orthography uses the Latin alphabet. There is no true standard orthography, only several locally more or less accepted orthographic guidelines. Those in the Netherlands are mostly based on Dutch orthography and those in Germany on German orthography. One of the mostly used orthographies can be found in modern official publications and internet sites, especially the Low German Wikipedia. This diversity, a result of centuries of official neglect and suppression, has a very fragmenting and thus weakening effect on the language as a whole, since it has created barriers that do not exist on the spoken level. Interregional and international communication is severely hampered by this. Most of these systems aim at representing the phonetic (allophonic) output rather than underlying (phonemic) representations but trying to conserve many etymological spellings. Furthermore, many writers follow guidelines only roughly. This adds numerous idiosyncratic and often inconsistent ways of spelling to the already existing great orthographic diversity.

In 2011, writers of the Dutch Low Saxon Wikipedia developed a spelling that would be suitable and applicable to all varieties of Low Saxon in the Netherlands, although the semi-official dialect institutes have not picked up on this, or indicated that they believed that yet another writing system will only further confuse dialect writers, rather than suit them.

\section{LANGUAGE USE AND LANGUAGE POLICY}

\section{The use of Frisian, its dialects and multilingualism}

Frisian is spoken in the province of Friesland, and in a few border villages in the neighbouring province of Groningen. The provincial government and the councils of several municipalities have started a language policy that - in principle - gives Frisian equal rights to Dutch. In the last decades the name of the province (Fryslân) and many local place names have officially been converted to Frisian.

Frisian contains a number of different dialects. Speakers from the clay region speak Klaaifrysk with a slightly different accent from speakers 
who live in the Wâlden 'woods' (Wâldfrysk). In the south-western part of Friesland there is yet another dialect in use (Súdwesthoeks). As a result of the commercial contacts with non-Frisian speakers, a mixed Dutch/Frisian dialect, the so-called 'Town Frisian' (Stedsfrysk or Stedsk) developed in the towns of Ljouwert (Leeuwarden), Snits (Sneek), Dokkum, Boalsert (Bolsward), Harns (Harlingen), Frjentsjer (Franeker) and It Hearrenfean (Heerenveen). In the town of Hylpen (Hindeloopen) a very archaic Frisian dialect is spoken, whereas the dialects of the islands Skylge (Terschelling), Skiermuontseach (Schiermonnikoog) also deviate substantially from the standard, which is mainly based on Klaaifrysk. On the other islands and in the areas of It Bildt a mixture of Dutch and Frisian can be heard, whereas in the south-eastern part of the province, the Stellingwerven, people speak Stellingwerfs, a Low-Saxon dialect.

The main dialects Klaaifrysk, Wâldfrysk and Súdwesthoeks are mutually intelligible, whereas the archaic dialect of Hylpen and Skylge differ a lot from the main dialects and are difficult to understand for other speakers of Frisian. A general standard of Frisian has been accepted, which is mainly based on the Klaaifrysk dialect. This is used in official announcements by the local government, in writing, in the media and in schools. Standard Frisian is quite conservative in nature, often resisting the use of Dutch loanwords long after they are firmly entrenched in spoken Frisian. But in view of the ease with which Dutch words are accepted into Frisian, sometimes supplanting very basic vocabulary items, these purist tendencies are certainly understandable. In his grammar Tiersma [Tiersma, 1985] has attempted, where variation exists, to include the most common form found in the literary and spoken language.

In the past the Town Frisian dialects had a higher prestige than Frisian, which was considered a farmer's language. Currently, however, Town Frisian is being replaced by Dutch and Frisian. At the beginning of the $20^{\text {th }}$ century the Ljouwert dialect, for instance, had a higher prestige than Frisian. During this century it has increasingly lost status to Dutch and Frisian and has become a sociolect that is now only spoken by the lower social classes. In recent years, however, there have been actions to encourage people to use their "Liwwadder" dialect.

Frisian and Dutch are both spoken in the province of Friesland, where Dutch as the official national language has the highest prestige. Frisian presently has got an official status in the Netherlands as the second language of the state. Its spelling has been standardised and Frisian 
is used in several domains of Frisian society, thereby breaking through the dominance of Dutch. Apart from domains such as the judiciary, public administration, radio and television, the Frisian language can also be used within the province for education. However, Dutch continues to dominate in economic, political and religious life.

It can be stated that the Frisian language is mainly spoken in the homes of Frisian people, in the countryside and in informal situations. In more formal surroundings, such as shops in town and government offices, many people shift to Dutch even if Frisian is their first language. In larger groups of people the presence of one Dutch speaking-person may suffice to trigger language shift of the whole group from Frisian to Dutch. Because of the fact that most Frisians (in particular the older ones) got their school education only in Dutch, many of them are not able to use the Frisian language in writing and prefer reading in Dutch. This is the main reason that the newspapers contain very little written Frisian.

The provincial government of Friesland and a number of municipalities make frequent use of both written and spoken Frisian. The regional broadcasting company Omrop Fryslân does radio and television broadcasts, where standard Frisian is well represented and accepted by speakers of the dialects. In the interviews on radio and television one can hear the dialects spoken in bilingual conversations, and Dutch also plays an important role. There are Frisian church services (the bible was translated into Frisian only in 1943), and every year Frisian language books are published and theatre plays performed.

The province of Friesland has about 600,000 inhabitants and about half of these can be considered first-language speakers of Frisian. A sociolinguistic study in 1994 revealed that $94 \%$ of the population of Friesland can understand the language, $74 \%$ can speak it, $65 \%$ are able to read Frisian (however, most of them read Dutch more easily) and $17 \%$ write Frisian. Frisian is spoken in $55 \%$ of the homes. Speakers of Frisian form a (great) majority in most rural areas, and a (small) minority in the towns and citites, on the Frisian Isles and in the Stellingwerven (two Low-Saxon municipalities in the southeastern part of the province). Practically all Frisian speakers are bilingual in Dutch. Most mothertongue speakers of Dutch in Friesland can understand Frisian, but are not able or not willing to speak it.

In the past language use in Friesland could be characterized as a stable diglossic situation (Frisian for the country and informal domains, 
Dutch for the town and formal domains). In the last century Dutch has also invaded the old Frisian domains (rural community matters and the family), primarily as a result of migration and mixed marriages. In this way the language use changed into a sort of informal (and receptive) polylingualism. General attitudes to Frisian have become more positive, and it has become acceptable to use it in more and more domains (radio, newspapers, etc).

As stated before, Dutch is still dominant in economic, political and religious spheres. Therefore Frisian is strongly influenced by it, particularly at the lexical level. More and more people say, for example, sleutel ["key"] rather than kaai, and boven ["above"] instead of boppe. On the other hand, the influences of Frisian on Standard Dutch are meagre some of the only words to have found entry into Dutch are those from typical Frisian sport terminology such as skûtsjesilen (competitive sailing with traditional sailing boats) and klunen (skating overland).

The third language in Friesland is English, which has growing importance in all parts of the Netherlands. As the European Union countries are becoming more united, English is increasingly being used as a means of general communication, in particular in international firms, commercial contacts, science, pop culture, higher education, etc. In many advanced courses in Dutch universities and similar educational institutions, English is used as medium for teaching, in particular with a growing group of students from abroad. This also holds for Friesland.

\section{Language policy}

Until recently a national language policy for Frisian has not been formally expressed by law, but in 2011 finally such a law has been prepared by the government. Official Dutch policy started with the 'Van Ommen Committee' (1970), which produced a report that recognised the responsibility of the national government with regard to Frisian. An important principle of the report was the recognition of Friesland as a bilingual province. The use of the Frisian language in specified domains is clearly restricted to the province of Friesland. The committee stated that the central government should focus on safeguarding the identity of the Frisian language and culture, in collaboration with provincial and municipal authorities. According to the report, this means that the national government has the function of resolving specific problems caused by bilingualism in the Frisian culture. 
In general, Frisian speakers can use their own language in contacts with public authorities, as the provincial administration and a number of other bodies have made this a matter of policy. Documents issued by public authorities generally are only in Dutch; Frisian or bilingual ones are very exceptional. In courts of justice all parties, including the defendant and witnesses, are allowed to speak Frisian. If need be, the court can employ the services of an interpreter. Courts of justice in Friesland accept civil actions brought in Frisian, but this can cause problems in case of an appeal to a higher court. Documents published in Frisian only are not legally binding. Public signs can be in Frisian, in Dutch, or bilingual, depending on the choice of the municipality concerned.

Current language policy regarding the Frisian language is based on the Frisian Language and Culture Covenant, an agreement between the provincial and the central government. This was drawn up in 1989, renewed in 1993, and redrafted in 2001 on the basis of the European Charter for Regional or Minority Languages [Gorter, 2005, Extra and Gorter, 2008]. This Council of Europe document was signed in 1992 and ratified by the Dutch government in 1996. With respect to Frisian it contains 48 concrete measures (part III), while other regional languages in the Netherlands obtained merely symbolic recognition from the national government (part II). In the covenant it is declared that it is desirable to make it possible for citizens, local authorities, organisations and institutions to express themselves in Frisian. The covenant also states that both provincial and central government are responsible for preserving and reinforcing the Frisian language and culture. Lastly, it states that resources must be provided to create suitable conditions for this purpose.

This means that:

- the national government determines the general education, culture and media policies in Friesland, although, as far as Frisian is concerned, it has to respect the European Charter;

- the province of Friesland determines the policy regarding the Frisian language and ensures the execution of this policy;

- the national government provides the province with the means to execute its policy as regards Frisian;

- the provincial policy concerning Frisian and the national policy concerning general education, culture and media have to reinforce each other where possible. 
The question of whether Low German should be considered a separate language, rather than a dialect of German or Dutch, has been a point of contention. Linguistics offers no simple, generally accepted criterion to decide this question. Scholarly arguments have been put forward in favour of classifying Low German as a German dialect. As said, these arguments are not linguistic but rather socio-political and build mainly around the fact that Low German has no official standard form or use in sophisticated media.

In contrast, Old Saxon and Middle Low German are generally considered separate languages in their own rights. Since Low German has undergone a strong decline since the $18^{\text {th }}$ century, the perceived similarities with High German or Dutch may often be direct High German/ Dutch adaptations due to the growing incapability of speakers to speak correctly what was once Low German proper.

Low German has been recognized by the Netherlands and by Germany (since 1999) as a regional language according to the European Charter for Regional or Minority Languages. Within the official terminology defined in the charter, this status would not be available to a dialect of an official language, and hence not to Low German in Germany if it were considered a dialect of German. Advocates of the promotion of Low German have expressed considerable hope that this political development will at once lend legitimacy to their claim that Low German is a separate language and help mitigate the functional limits of the language that may still be cited as objective criteria for a mere dialect (such as the virtually complete absence from legal and administrative contexts, schools, the media, etc.).

In the following sections we shall consider the position of Frisian within the Netherlands as an example of one of the European minority and regional languages and present information about the work of some organizations involved in the safeguarding and study of these languages.

\section{REFERENCE WORKS RELATED TO FRISIAN AND OTHER MINORITY LANGUAGES}

De Graaf T., Tiersma P. Some phonetic aspects of breaking in West-Frisian. Phonetica, 1980, vol.37, pp. 109-120.

Epp R. The Story of Low German and Plautdietsch. Tracing a Language across the Globe. Hillsboro, Kansas, USA, The Reader's Press, 1993. 210 p. 
European Charter for Regional or Minority Languages (1998) Explanatory Report. (ETS no. 148) Strasbourg: Council of Europe, 1998. 38 p.

Extra G., Gorter D. The constellation of languages in Europe: an inclusive approach. Multilingual Europe: Facts and Policies. Eds G. Extra, D. Gorter. Berlin, Mouton de Gruyter, 2008, pp. 3-60.

Gorter D. Three Languages of Instruction in Fryslân. International Journal of the Sociology of Language, 2005, vol. 171 (2005), pp. 57-73.

Gorter D., Van der Meer C. , Riemersma A. Multilingual Europe: Facts and policies. Eds G. Extra, D. Gorter. Berlin, Mouton de Gruyter, 2008, pp. 185-206.

Kodama H. Furizija Bunpo (Frisian Grammar). Tokyo, Daigakusyorin, 1992. $292 \mathrm{p}$.

Nieuweboer N. The Altai Dialect of Plautdiitsch (West-Siberian Mennonite Low German). München, Lincom Verlag, 1999. 256 p.

Sanders Chr. Sachsensprache, Hansesprache, Plattdeutsch. Sprachgeschicht-liche Grundlagen des Niederdeutschen. Göttingen, 1982.278 p.

Shimizu M. Nishi Furizija Bunpo (West Frisian Grammar). Sapporo, Hokkaido University Press, 2006. 120 p.

Tiersma P.M. Frisian Reference Grammar. Dordrecht, Foris Publications, 1985. $147 \mathrm{p}$.

\section{REFERENCES TO RELATED WEBSITES}

Further information can be found in the following websites about Frisian and other minority languages. Part of this report is based on texts from these websites.

www.fa.knaw.nl

Website of the Frisian Academy

www.languages-on-the-web.com/links/link-frisian.htm

General information about Frisian and its relation to other languages

www.tiersma.com.frisian/frisian.htm

Website by the Frisian-American author Peter Tiersma

www.eurolang.net/languages/frisian.htm

Minority Languages Archive

www.mercator-research.eu

Homepage of the Mercator Research Centre. The site contains the series of regional dossiers, the network of schools, a database with organisations and bibliography and many rated links to minority languages.

www.mercator-network.eu/

The Mercator European Network of Language Diversity Centres and portal for the partners of the network

www.aber.ac.uk/ merc/ 
Homepage of Mercator-Media. It provides information on media and minority languages in the EU.

\section{Тьеерд Де Грааф}

доктор физических наук (теоретическая физика), магистр гуманитарных наук, лингвистика (славянские языки, компьютерная лингвистика), старший научный сотрудник, Фризская Академия, Европейский исследовательский центр многоязычия и обучения языкам Фризская Академия, Леуварден, Нидерланды

E-mail: tdegraaf@fryske-akademy.nl

\section{Tjeerd de Graaf}

$\mathrm{PhD}$ in Theoretical Physics, Master of Arts in Linguistics (Slavic Languages, Computer Linguistics), senior research associate at the Frisian Academy and the European Research Centre on Multilingualism and Language Learning Fryske Akademy, Doelestrjitte 8, 8911 DX Ljouwert, The Netherlands

E-mail: tdegraaf@fryske-akademy.nl

Статья поступила в редакцию 18.03.16, принята к публикации 19.05.16 